MOSAIR journal

Herausgegeben von
Maria Kristina Lahn und
Maren-Grischa Schröter

Band 1 (2010)

- Raumdimensionen im Altertum -

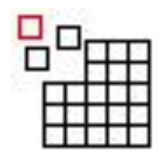





\section{INHALTSVERZEICHNIS}

Inhaltsverzeichnis $\quad \mathrm{v}-\mathrm{vi}$

Vorwort vii-viii

Raumdimensionen im Altertum - Über die Anwendbarkeit des spatial turn in den historischen Wissenschaften

Maria Kristina Labn - Maren-Grischa Schröter

$1-8$

Vorgestellte Orte und utopisches Denken im Alten Ägypten

Janne Arp

Lokale Kulttraditionen vs. "semitisches Pantheon". Eine "männliche Tyche" in Dura Europos

Julian Buchmann

Domestic Space and Community Identity in the Aegean Islands and Crete 1200-600 BC

Anastasia Christophilopoulou

"Ritual Landscape" und "Sacred Space". Überlegungen zu Kultausrichtung und Prozessionsachsen in Abydos

Andreas Effland - Ute Effland

Zwischen Kult und Kommerz. Architektur als erfahrbarer Raum in antiken Orakelheiligtümern

Wiebke Friese

Magische und reale Räume im Tempel von Edfu Jan-Peter Graeff 
The Spatial Adjunct in Middle Egyptian: Data from the Coffin Texts

Carlos Gracia Zamacona

$221-258$

Sepulkrale Hofarchitekturen im Hellenismus. Ein Vorbericht zur Architektur und Funktion ausgewählter Grabanlagen in Alexandria, Kyrene und Nea Paphos

Anika Greve

The Relationship between the Space and the Scenery of an Egyptian Temple: Scenes of the Opet Festival and the Festival of Hathor at Karnak and Deir el-Bahari under Hatshepsut and Thutmose III.

Alexandra V. Mironova

Räumliche Dimensionen historischer Gesellschaften - ein Kommentar

Susanne Rau

$331-344$ 


\section{VORWORT}

Interdisziplinäres Arbeiten, multiperspektive Forschung und die Nutzung moderner Medien sind zu festen Bestandteilen der heutigen Wissenschaftslandschaft geworden. Diesen Leitideen folgend, wurde MOSAIKjournal 2009 gegründet, um die Zusammenarbeit zwischen den altertumswissenschaftlichen Disziplinen und die Entstehung wissenschaftlicher Netzwerke zu fördern.

In den einzelnen Ausgaben von MOSAIKjournal werden daher Beiträge unterschiedlicher Fächer unter einem thematischen Schwerpunkt vereint. So widmet sich der vorliegende Band etwa den Raumdimensionen im Altertum und versammelt dabei Aufsätze aus der Ägyptologie, der Prähistorischen und Klassischen Archäologie und der Geschichte der Neuzeit.

MOSAIKjournal erscheint einmal jährlich als Online- und Print-Version. Die Web-Präsenz (www.mosaikjournal.com) gewährleistet nicht nur einen unbeschränkten Zugriff auf alle Artikel, sondern auch ein unkompliziertes und zeitnahes Publizieren; darüber hinaus wird jede Ausgabe auch als gedruckte Fassung bei Gorgias Press (NJ, USA) herausgegeben.

Es verbleibt noch der Dank an die Kolleginnen und Kollegen, die maßgeblich an der Fertigstellung der ersten Ausgabe des Journals beteiligt waren. Wir danken ganz besonders Anika Greve, die uns bei den redaktionellen Arbeiten tatkräftig unterstütze sowie Wiebke Friese, Andrea Harms und Falko Schnicke für die Durchsicht der Manuskripte. Susanne Rau versorgte uns in der Entstehungsphase des ersten Bandes mit hilfreichen Tipps und Hinweisen und bereicherte den Band mit ihrem synthetisierenden Kommentar der Einzelbeiträge. Für die engagierte Unterstützung sei ihr herzlichst gedankt. Auch die angenehme und unkomplizierte $\mathrm{Zu}$ sammenarbeit mit Gorgias Press, insbesondere mit Katie Stott, bei der Erstellung der Print-Version hat uns stets viel Freude bereitet. 
Ein besonderer Dank gebührt schließlich auch allen Autorinnen und Autoren, die durch ihre Artikel und Anregungen in zahlreichen Diskussionen dazu beigetragen haben, dass wir mit MOSAIKjournal 1 (2010) einen facettenreichen Band zu den Raumdimensionen im Altertum vorlegen können.

Hamburg, im Januar 2011

\author{
Maria Kristina Lahn \\ Maren-Grischa Schröter
}




\title{
The Spatial AdJunCt IN MIDdle EGYPTIAN: DATA FROM THE COFFIN TEXTS
}

\author{
CARLOS GRACIA ZAMACONA
}

\begin{abstract}
This paper aims to describe the spatial adjunct ( $S A$ ) of motion verbs in the Middle Egyptian of the Coffin Texts. Verbs expressing both position and displacement are understood here as "motion verbs". After a brief presentation of the corpus and methodological approach, a basic theoretical framework is proposed, followed by a description of the spatial adjunct in the domain of the verbal sentence. Notions of interior space, the nature of space and limited/unlimited space are analysed, showing their relevance to the subject under study. This is followed by some theoretical reflections on the valential position of the spatial adjunct and its closeness to direct and indirect objects. In this respect, G. Lazard's concept of "objectal zone" seems to be very useful. Finally, the resulting twelve spatial functions are illustrated with their respective tables, showing the prepositions used according to the criteria imposed on the description.

Der Beitrag behandelt die räumliche Ergänzung der "Verben der Bewegung" im Mittelägyptischen der Sargtexte. Als "Verben der Bewwegung" werden dabei solche aufgefasst, die eine Position oder eine Ortsveränderung ausdrücken. Nach einer kurzen Darstellung des Corpus' und der methodischen Herangehensweise wird ein methodischer Rahmen
\end{abstract}


entwickelt, gefolgt von einer Beschreibung der räumlichen Ergänzung im Zusammenhang mit dem Verbalsatz. Die unterschiedliche Wahrnehmung von Innenräumen und die Analyse unterschiedlicher Charakterisierungen von unbegrenztem und begrenztem Raum sind in der vorliegenden Studie von besonderer Bedeutung. Es folgen theoretische Überlegungen über die Valenzposition der räumlichen Ergänzung und über deren Nähe zu direkten und indirekten Objekten. In diesem Zusammenhang erweist sich G. Lazards Begriff der "objectal zone" als sehr nützlich. Abschließend werden die erarbeiteten zwölf räumlichen Funktionen in ibren jeweiligen Tabellen dargestellt, unter Angabe der Präpositionen nach Maßgabe der in der Beschreibung entwickelten Kriterien.

\section{ABBREVIATIONS USED FOR THE GLOSSES}

\begin{tabular}{|l|l|}
\hline $1,2,3$ & First, second, third person \\
\hline D & Dual \\
\hline EXCL & Exclamation \\
\hline FUT & Feminine \\
\hline IMPL & Future \\
\hline INF & Implicative \\
\hline M & Infinitive \\
\hline MOD & Masculine \\
\hline N & Modal \\
\hline NEG & Deceased's proper name \\
\hline PART & Negation \\
\hline PARTIT & Particle \\
\hline PFV & Partitive \\
\hline PL & Perfective \\
\hline SG & Plural \\
\hline
\end{tabular}




\section{CORPUS AND CRITERION}

The aim of this paper is to present a general description of the spatial adjunct (SA) in Middle Egyptian according to the data from the Coffin Texts $(\mathrm{CT})^{1}$ and from a semantic viewpoint. ${ }^{2}$ In order to do so, the prepositions ${ }^{3}$ introducing an SA with motion verbs have been systematically and exhaustively studied in the Coffin Texts, the main funerary corpus written in Middle Egyptian (c. 2000-1500 BC): In all, more than 5,000 study cases have been individualised and taken into consideration. ${ }^{4}$

Any verb with the valential structure $\mathrm{p}_{1}$ (first participant: agent $)+$ verb $+p_{2}$ (second participant: space) has been considered as a motion verb. ${ }^{5}$ The term agent is taken here in its broadest sense (not as opposed to undergoer): It is not the agent that is correlated by a patient. ${ }^{6}$ This structure partially corresponds to that set out by R. W. Langacker as trajector $\left(\mathrm{p}_{1}\right)$ and landmark $\left(\mathrm{p}_{2}\right) \cdot{ }^{7}$ The second participant of a motion verb so defined, i. e. the spatial adjunct, may be a directional (provenance ${ }^{8}$, course ${ }^{9}$ or destination ${ }^{10}$ )

1 De Buck's edition is used, quoted as usual in Egyptological literature as CT: see references.

2 DANeš (1964); HagÈge (1996); MALAise - WinAND (1999) 203-204; WINAND (2006) 7.

3 On prepositions, in general, see GuILLEMIN (1920); BRøNDAL (1950); POTTIER (1962); LOPEZ (1970); BERTHONNEAU - Cadiot (1993); SAint-Dizier (2005); PApahagi (2005). On Egyptian prepositions, see LE PAGE RENOUf (1873); ERMAN (1928) SS 442-456; SMITHER (1939); CLERE (1941-1947); GARDINER (1957) chap. XIV; SANDER-HANSEN (1956) SS 289-308; DEINES - WESTENDORF (1957); ANTHES (1969); JUNGE (1973); ROCCATI (1975); HANNIG et al. (1986); LOPRIENO (1995) S 4.7; MALAISE - WinAND (1999) chap. XVI; ALLEN (2000) SS 8.1-8.10.

${ }^{4}$ GRACIA (2008).

5 LEMARECHAL (1989) 204. 207-208; LAZARD (1994) 98; PALMER (1996) 5. 32-33. 201.

6 For the mutual relationship between agent and patient, see DOWTY (1991).

${ }^{7}$ LANGACKER (1987) \ 6.3 (mainly page 234).

8 The term source is frequently used in linguistic literature written in English.

9 The term path is sometimes used: see for example SvOROU 
or a locative. In the first case, the verb is a displacement verb; in the second case, a position verb. ${ }^{11}$ It seems clear that the term motion verbs is not the most appropriate for this kind of verb, which would be better labelled as spatial verbs, but the term is already habitual in specialised literature and it would be pointless to reject it, as it turns out to be linguistically relevant. ${ }^{12}$

\section{THEORETICAL FRAMEWORK}

For simple practical purposes, and in order to obtain a general description of the SAs, the following theoretical framework of spatial functions ${ }^{13}$ is accepted. It results from combining the features of provenance, course, destination and locative, on the one hand, with those of inside, outside and general, on the other: ${ }^{14}$

\begin{tabular}{|l|l|l|l|l|}
\hline $\begin{array}{l}\text { SPATIAL } \\
\text { FUNCTIONS }\end{array}$ & Provenance & Destination & Course & Locative \\
\hline Inside & $\begin{array}{l}\text { Elative } \\
\text { (from inside) }\end{array}$ & $\begin{array}{l}\text { Illative } \\
\text { (into) }\end{array}$ & $\begin{array}{l}\text { Endo-coursive } \\
\text { (through) }\end{array}$ & $\begin{array}{l}\text { Inessive } \\
\text { (in) }\end{array}$ \\
\hline Outside & $\begin{array}{l}\text { Ablative } \\
\text { (from } \\
\text { outside) }\end{array}$ & $\begin{array}{l}\text { Allative } \\
\text { (to) }\end{array}$ & $\begin{array}{l}\text { Exo- } \\
\text { coursive } \\
\text { (by) }\end{array}$ & $\begin{array}{l}\text { Adessive } \\
\text { (out of) }\end{array}$ \\
\hline General & $\begin{array}{l}\text { Originating } \\
\text { (from) }\end{array}$ & $\begin{array}{l}\text { Conclusive } \\
\text { (to, towards) }\end{array}$ & $\begin{array}{l}\text { Coursive } \\
\text { (via) }\end{array}$ & $\begin{array}{l}\text { Essive } \\
\text { (at) }\end{array}$ \\
\hline
\end{tabular}

Table 1

(1994) 27-29.

10 The term goal is usually employed.

11 LAZARD (1994) 129.

12 Gracia (2008) 1516-1518.

${ }^{13}$ For the localist(ic) theory, see JESPERSEN (1924) chap. XIII; HJelmsleV (1935) I I, B, 2; KURILOWICZ (1949); PotTIER (1962); Fillmore (1968); ANDERSON (1971); BENNET (1972); DieHL (1975); DervilleZ-BASTujI (1982) chap. XXI; LAMIROY (1988)

55; LYONS (1994) \15.7.

14 LYONS (1971) \ 7.4.6; COMRIE - SMITH (1977) \ 2.1.1.5.

15 This seems to correspond to the Finnish prolative case. 
The English paraphrase proposed in brackets is merely indicative of the meaning: It is clear that it may change depending on the context.

Although this scheme as it stands is useful for a purely theoretical first approach, further features will nevertheless be required to explain the use of the basic spatial prepositions in the Coffin Texts, as I intend to demonstrate in this paper.

First of all (paragraphs 3-5), I propose to analyse the oppositions between these prepositions, to try and deduce their meaning from their uses. Then (paragraph 6) an interpretation of the different semantic functions of the spatial adjunct in the Middle Egyptian of the Coffin Texts is set out.

\section{PRESENCE OR ABSENCE OF INTERIOR SPACE}

In Egyptian, the basic spatial prepositions are ambiguous concerning the direction of motion, as is clearly exemplified by the well known formula of the passage of the deceased: ${ }^{16}$

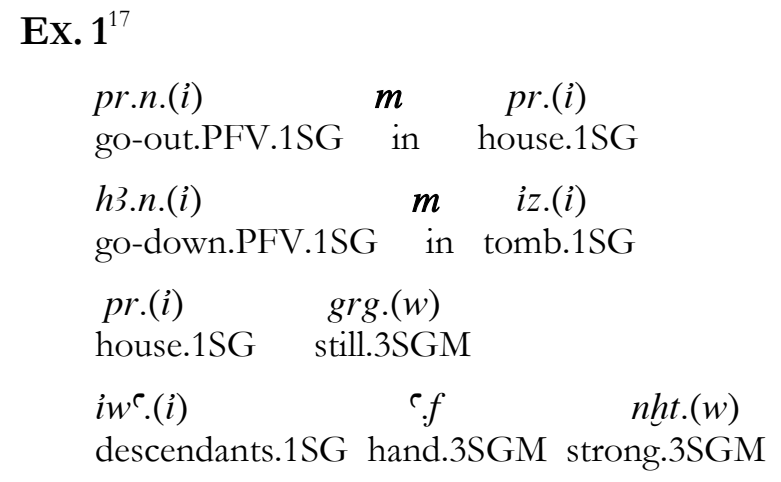

16 Polotsky (1965) 14; see also Goedicke (1955) and ASSMANN (2001) chap. 13.

17 Implicite elements are written in round brackets. All other philological signs are omitted in this paper. Glosses are reduced to a minimum, mainly those specifically relating to Egyptian grammatical issues. 
"It is only my house being still (and) my descendants, their hand, being strong, that I have gone up out of my house (and) that I have gone down into my tomb."

This passage shows quite clearly that the preposition $m$ can mean either the provenance or destination space, but this is not inherent to the meaning of this preposition. What is pertinent to the meaning of the preposition $m$ is the existence or the absence of interior space for the entity marked by it: $m$ can only follow a motion to or from inside a space (i. e. illative or elative).

The same may be said about the preposition $r$, but this time, it is exteriority in relation to an entity with interior space which is expressed: $r$ may mark motion to or from outside a space (i. e. allative or ablative)..$^{18}$ This fact becomes quite clear when two verbs of opposed directions are both followed by one and the same SA:

\section{Ex. 2 (CT IV 82 d)}

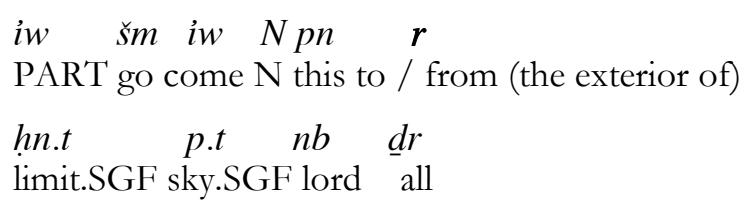

"This $\mathrm{N}$ goes to (the exterior of) (and) comes from (the exterior of) the limit of the sky of the Lord of All."

It thus seems that the opposition inside $(m) /$ outside $(r)$ is only possible with entities possessing interior space. Entities lacking interior space have this opposition neutralised and are usually marked by $h r$ (originating and conclusive functions) ${ }^{19}$, as is the case of $w^{r} r . t$ "plateau", whose originating function may be exemplified by

\section{Ex. 3 (CT III 257 c)}

zwr.k $\quad m \quad n w(n)$ m.w

drink.2SGM of these water.PLM

\footnotetext{
18 FRANKE (1998) 52-53.

19 The Hebrew preposition על "on” behaves very similarly.
} 
w'b.w pr.w

pure.PLM spring.PLM

hr wer.t tw n.t niw.tyw

on plateau.SGF that of.SGF citizen.PL

"May you drink of these pure waters sprung out from that plateau of the citizens!"

Its conclusive function also occurs in

\section{EX. 4 (CT VI 247 1)}

iw.k3.f $\quad h r w^{\top} r . t \quad t w \quad n . t$
come.FUT.3SGM on plateau.SGF that of.SGF
inn.w $\quad n h n h h$
expectation.SGM child

"[...] then he will come to that plateau of child expectation."

In general linguistics, it has already been remarked that there are prepositions which introduce terms which must possess a "dimension", while other terms are not specified in this sense. ${ }^{20}$ In Egyptian, A. H. Gardiner had already noted the "indefinition" of the preposition $h r .{ }^{21}$ In consequence, the question is to determine which entities possess interior space and which do not. In order to obtain a description of all analysed cases, an overall study of spatial prepositions has been carried out on the Coffin Texts. I present here, in summary, the conclusions of this study.

\section{1.}

Animate non-divine entities have no interior space, but in the plural (with the preposition $\mathrm{mm}$ "among") and dual (with the preposition imytw "between") they behave as if they did. So, see

${ }^{20}$ LÓPEZ (1970) 79; WAUGH (1976); LAFFORD (1986) 553564; LYONS (1994) 696-697. 703.

21 GARDINER (1957) \165.1. 


\section{Ex. 5 (CT IV 346 c)}

$m \quad$ iw $\quad h r . i$

NEG come on.1SG

"Do not come towards me (= N)!",

but

\section{Ex. 6 (CT VI 276 I)}

i ntr pw prr h3.f

EXCL god that go-up go down.3SG

mm.sn 'nh.w

among.3PLM living.PLM

"Oh, you god who goes up, one who goes down among them, the living!"

Animate collectives may behave either like plurals (preposition $\mathrm{mm}$ ) or like inanimates (preposition $m$ ):

\section{Ex. 7 (CT VII 384 b)}

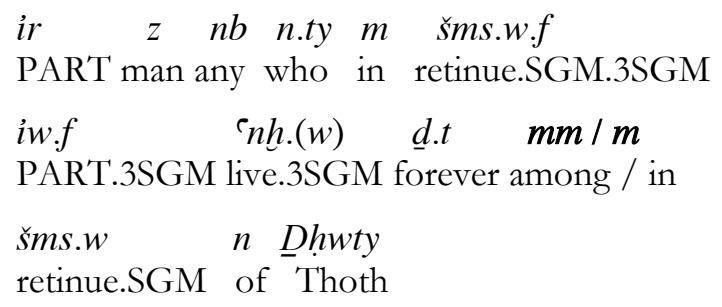

"As for any man who (is) in his retinue, he lives forever among / in the retinue of Thoth."

When an animate seems to possess interior space, such a term appears instead of the term "body" or similar: In the Coffin Texts, this is very typical of the deceased. For instance, in 


\section{Ex. 8 (CT IV 330 1)}

$n(n) \quad$ hb.w ds.w.sn im.i

NEG sink.FUT knife.PLM.3PL in.1SG

"Their knives shall not sink into me."

\section{2.}

All animate divine entities possess interior space: The preposition $m$ can be used with them. For example, in

\section{Ex. 9 (CT VI 198 a)}

ink wnb $p r \quad m \quad R^{e} \quad{ }^{c} w^{e} \quad p r$

me flower issued in $\operatorname{Re}$ flower issued

$m$ 3h.t

in horizon.SGF

"It is me the wnb-flower which issued from Re, the ' $w$ ' flower which issued from the horizon."

\section{3.}

Inanimate entities can possess or lack interior space.

\subsection{1.}

Inanimate entities with interior space are the following:

- buildings, parts of buildings and seats:

\section{Ex. 10 (CT I 41 b)}

pr $\quad n . k \quad m \quad$ pr.k
go-out IMPL in house.2SGM
$m \quad$ s.t.k $\quad m \quad b w \quad n b$
in place.SGF.2SGM in place any
ntk im
2SGM there

"Go out, you, from your house, from your place, from any place where you (are)!" 
- containers in the broad sense (e. g. vases, nets, baskets, boxes, ships):

\section{Ex. 11 (CT VII 473 m)}

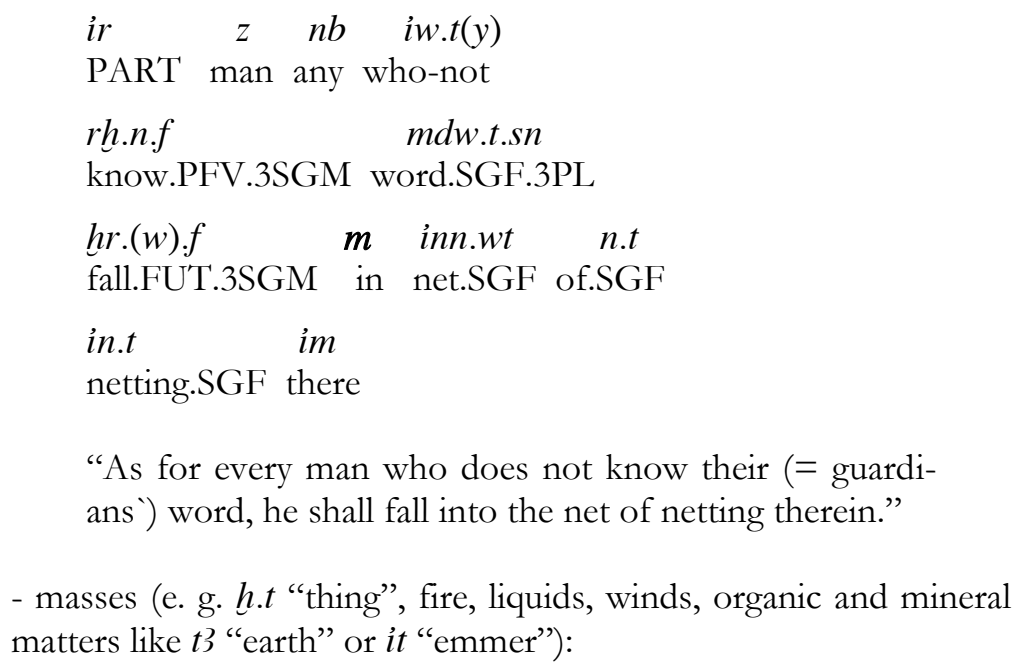

- masses (e. g. h.t "thing", fire, liquids, winds, organic and mineral matters like $t$ ? "earth" or it "emmer"):

\section{Ex. 12 (CT III 337 a)}

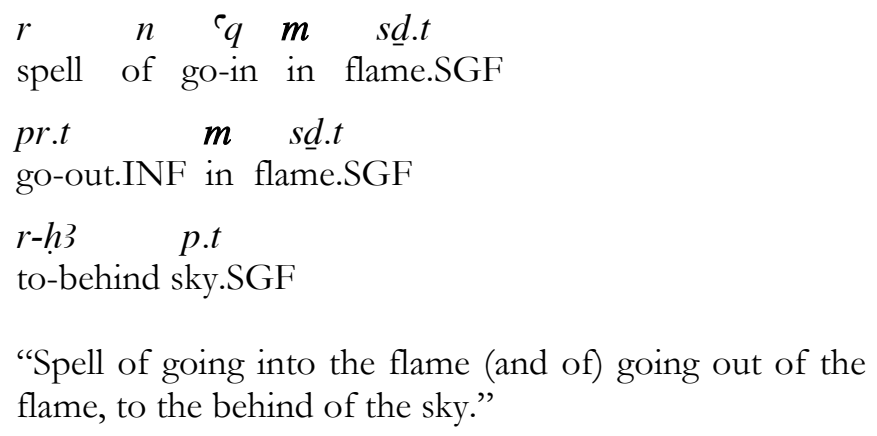

- natural sites or territorial divisions conceived as having volume (e. g. 3h.t "horizon", i3.t "mound"):

\section{Ex. 13 (CT II 37 g)}

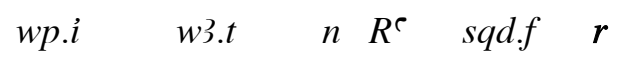


3h.t imn.tt
horizon.SGF western.SGF

"May I open a way for Re, for him to sail to the western horizon!"

- body parts with cavities (e. g. ib "heart", r "mouth"):

\section{Ex. 14 (CT V 397 j-1)}

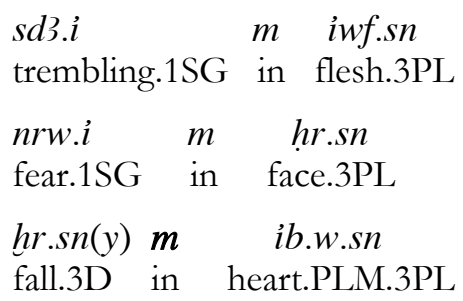

"Trembling of me (is) in their flesh, fear of me (is) in their faces (as) both of them fall into their hearts."

- plants:

\section{Ex. 15 (CT IV 153 f)}

$\begin{array}{lcc}h^{e} & i r . t & R \\ \text { appear } & \text { eye.SG } & \text { Re-Atum }\end{array}$

m bb.t

in $b b . t$-plant.SGF

"The eye of Re-Atum has appeared in the bb.t-plant."

- deictic terms (e. g. '3 "here”, tn "where?”):

\section{Ex. 16 (CT V 167 D)}

$$
\begin{aligned}
& \text { h(3).y } m \text { htp 3h 'pr } n \\
& \text { go-down.MOD in peace spirit equipped of } \\
& z \check{s} n . t \quad h f t \text { s3h } m \text { p.t rs.t } \\
& \text { zSn.SGF like Orion in sky.SGF southern.SGF }
\end{aligned}
$$


$r \quad t n \quad z p \quad 2 \quad r \quad b w$

to where time 2 to place

$n t(y) \quad$ wsir im $r \quad r d(w)$

which Osiris there to stairs

"May the equipped spirit of the $z \check{s} n . t$-building go down in peace like Orion (does) in the southern sky! To where? -twice- To the place where Osiris is, to the stairs."

- zones of light and darkness (e. g. šw "sunlight"):

\section{Ex. 17 (CT IV 50 I)}

\section{[...] hms.i $m$ šw $\check{s} y . t$ sit.1SG in sunlight dry-wind.SGF}

"[...] that is for me to sit down in the sunlight, in the dry wind."

- durative actions (e. g. iw.t "come"), states (e. g. b3g "inertia"), nominalised actions (e. g. phr.t "circuit") and some temporal divisions (e. g. wnw.t "hour"):

\section{Ex. 18 (CT VII $214 \mathrm{~g}$ )}

\begin{tabular}{|c|c|}
\hline$n . i$ & $\begin{array}{c}m p h r . t \quad n . t \quad \text { iwn } \\
\text { in circuit.SGF of.SGF pillar }\end{array}$ \\
\hline mh.tt & $w b 3$ \\
\hline
\end{tabular}

Horus north.SGF hole darkness

"It is out of the circuit of Horus' pillar, which (is) in the north of the hole of darkness, that I have come."

\subsection{2.}

Inanimate entities without interior space are less numerous. These are:

- body parts without cavities (e. g. $n s$ "tongue"): 


\section{Ex. 19 (CT VI 376 h)}

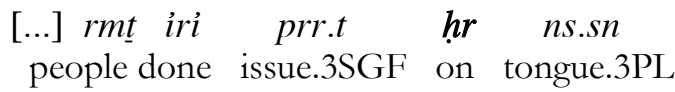

"[...] people who have done what issues from (lit. on) their tongue."

- "surfaces" (e. g. h3s.t "steppe", w3.t "way"):

\section{Ex. 20 (CT II $150 \mathrm{~g}-\mathrm{i}$ )}

h33.k hr w3.t imn.tt

go-down.2SGM on way.SGF western.SGF

$\underline{d} r-n t t \quad$ 3.(s) $\quad n \underline{d}$ m.s

because large.3SGF pleasant.3SGF

qsn i3b.tt sr.s

difficult eastern.SGF small.3SGF

"It is upon the western way that you go down, because it is large (and) pleasant, (whereas) the eastern one is difficult (and) small."

- "lines" like supporting elements (e. g. wdh "offering table") and closing elements (e. g. inb "wall”, inm "skin"):

\section{Ex. 21 (CT I 263 c-d)}

$$
\text { zwr.k h3.w } n \text { irt.t pr }
$$

drink.2SGM bowl.SGM of milk.SGF issue

hr wdh.w hrw sn.wt

on offering-table.PLM day $6^{\text {th }}$-day-feast

"May you drink the bowl of milk issued from the offering tables on the $6^{\text {th }}$ day feast!"

- punctual actions (e. g. dd.t.n.f "what he has said") and "negative" actions (e. g. iw. $t t$ "non-existence"): 


\section{Ex. 22 (CT I 385 a-b)}

$$
\begin{array}{lcc}
{[\ldots]} & \underline{h p r}-\underline{d} s . f \quad \text { iwty } & w \underline{d b} b . n . f \\
& \text { Self-created who-not return.PFV.3SGM } \\
h r & \underline{\text { dd.t.n.f }} & {[\ldots]} \\
\text { on } & \text { say.SGF.PFV.3SGM }
\end{array}
$$

"[...] the Self-created, who never returns from what he has said [...]."

\section{4 .}

The preposition $m$ can replace the prepositions (mainly $h r$ ) marking entities without interior space in the case of resumptive, massive, plural and dual SAs.

\section{Ex. 23 (CT IV 53 d)}

$$
\begin{aligned}
& \text { iri } \quad n . \dot{i} \quad \text { w3.t } \quad s w 3 . i \quad \mathbf{i m}^{22} . s \\
& \text { make for.1SG way.SGF pass.1SG } \quad \text { in.3SGF } \\
& \text { "Make me a way, that I may pass by it!" }
\end{aligned}
$$

\section{5.}

SAs with interior space tend to be transitivized better than SAs without interior space (14 to 1), but this may not be pertinent because, as I said, the first kind of SA is much more numerous than the second. Transitivization is mainly present with SAs of course and destination: And this is really relevant.

\section{6.}

Entities without interior space can not fulfill spatial functions with the feature "inside", i. e. elative, illative, endo-coursive and inessive.

\section{NATURE OF THE SPACES}

SA's entities can be animate or inanimate. This opposition is clear for the allative: $r$ is used for inanimates and $n$ for animates. ${ }^{23}$

\footnotetext{
22 Proclitic writing of the preposition $m$.
} 


\section{Ex. 24 (CT I 12 b)}

iw.t.k $\quad r \quad$ niw.t wr.t

come.MOD.2SGM to town.SGF great.SGF

"May you come to the great town!"

\section{Ex. 25 (CT V 363 e)}

\begin{tabular}{|c|c|c|}
\hline & $p$ & $\boldsymbol{n} \quad$ ini.(w) \\
\hline
\end{tabular}

"May I cross and go up to him who brought him (= the god Hotep)!"

The same mark (preposition $n$ ) is used for animate allative and indirect object ${ }^{24}$, which sometimes makes it difficult to distinguish between the two. A. Roccati remarked implicitly on the opposition $r / n$ for the allative when he wrote about the preference of the verb $i$ I $i w$ "come" for the preposition $n^{25}$, a preference well attested in the Coffin Texts, because 10 out of the 14 animate allatives follow that verb. This is due to the deictic character of the verb $i i$ / $i w$, which expresses a motion towards the speaker (12 out of 14 animate non-divine allatives are in the first person singular) or the place where (s)he is, either really or psychologically. ${ }^{26} \mathrm{It}$ is obvious that the speaker being an animate, the preposition $n$ is used. As a matter of fact, the allative is the only spatial function that this preposition can mark and this is almost anecdotal when compared to the hundreds of examples of $n$ as a mark for the indirect object.

23 GARDINER (1957) \164.1.

24 According to PALMER (1994) 32-33 the feature that allows the semantic unity between beneficiary and allative is precisely animacy (and human).

25 ROCCATI (1975).

26 Fillmore (1966); Fillmore (1983); Depuydt (1985a); DEPUYDT (1985b). 
Nevertheless, a further distinction must be made, since the allative of divine entities is marked by the preposition $h r .{ }^{27}$

\section{Ex. 26 (CT IV 56 c)}

\begin{tabular}{|c|c|c|}
\hline $\begin{array}{l}\text { it.i } \\
\text { father.1SG }\end{array}$ & $\begin{array}{c}\text { wsir } \\
\text { Osiris }\end{array}$ & $\begin{array}{c}m k \\
\text { PART }\end{array}$ \\
\hline $\begin{array}{l}k w i \\
k \text { ome.1 }\end{array}$ & $\begin{array}{c}h r \cdot k \\
\text { 2SGM }\end{array}$ & \\
\hline
\end{tabular}

"My father, Osiris! Here I am coming to you."

In this case, no confusion is possible between the allative (with $h r$ ) and the indirect object (with $n$ ).

\section{Ex. 27 (CT VII 37 c-d)}

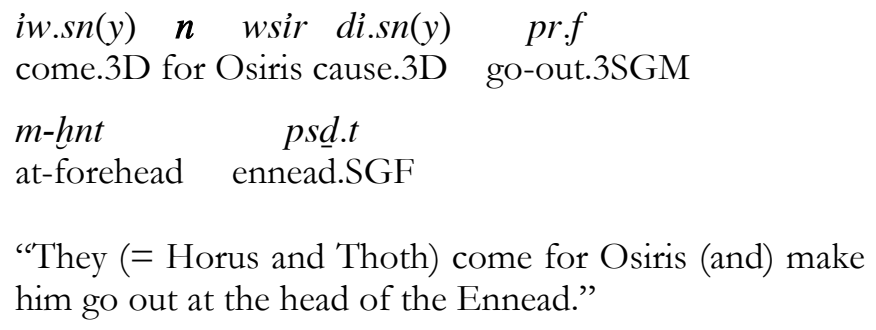

Now, we saw in paragraph 3.2 that only divine animates among all animates have interior space. It seems that the allative preposition $h r$ is in the middle of an animacy gradient between the inanimate allative preposition $r$ and the animate allative preposition $n$ : In fact, the basic meaning of the preposition $h r$ is "in the area of". ${ }^{28}$ In other words, divine animates (gods and other divine-like entities) are considered in Egyptian as "areas" having a specific character.

27 In the Pyramid Texts, this preposition can also mark inanimates, apparently non-divinised (PT $\int 1188 \mathrm{c}-\mathrm{d}$ ); see ANTHES (1954) 46 and n. 160 and animates (PT \1160 a); see EDEL (19541964) $\int 768$.

28 EDEL (1954-1964) S 768 (a). 
A last category of entities, concerning nature, should be taken into account: divinised inanimates. ${ }^{29}$ It is the case, among others, of $i z$ "tomb", doors, and boat parts. For example, the tomb (a divinised inanimate) can say to the deceased:

\section{Ex. 28 (CT I 182 h)}

$\begin{array}{lccc}\text { imi } & z b .(w) & \underline{t} w & r . i \\ \text { cause } & \text { pass.SGM } & \text { 2SGM } & \text { to.1SG }\end{array}$

"Do proceed (lit. make the proceeding, you,) to me!"

Here, the preposition $r$ marks the allative, and not, as would be the case for an animate, the opposition case: Divine inanimates are marked the same way as inanimates.

\section{SPACES WITH OR WITHOUT A LIMIT}

The notion of limit $^{30}$ may seem less usual than those of space and animacy considered in the previous paragraphs, but it has not been completely disregarded in general linguistics; for example, in G. Lakoff and M. Johnson's words:

"We are physical beings, bounded and set off from the rest of the world by the surface of our skins, and we experience the rest of the world as outside us. Each of us is a container, with a bounding surface and an in-out orientation. We project our own in-out orientation onto other physical objects that are bounded by surfaces. Thus we also view them as containers with an inside and an outside. (...) even where there is no natural physical boundary that can be viewed as defining a container, we impose boundaries (...)".31

29 LAZARD (1994) 192 and n. 1.

30 The importance of this idea in Egyptian culture has been emphasized by HORNUNG (1996) 79-92; ENGLUND (1999); BRUNNER-TRAUT (2002) 430-440, who quotes Alois Riegl as the one who first recognized it.

31 see LAKOFF - JOHNSON (1980) 29. For the notion of limit applied to the Greek verb $\beta \alpha i v \omega$, see LÉTOUBLON (1985) 138-140. 
In Egyptian, the notion is well expressed by the preposition $r^{32}$. An excellent example of this feature of the preposition $r$ is:

\section{Ex. 29 (CT VI 23 o) ${ }^{33}$}

$$
\begin{aligned}
& n \text {-ntt } \quad N \quad p n \quad r h .(w) \quad s(y) \\
& \text { because } \mathrm{N} \text { this know.3SGM 3SGF } \\
& r \quad d b 3 . w \quad h r . w \\
& \text { from float.PLM upper.PLM } \\
& r \quad \underline{d n s . w t} \quad \underline{h} r .(w) t \\
& \text { to weights.PLF lower.PLF }
\end{aligned}
$$

"Because this $\mathrm{N}$ knows it (= the net) from the upper floats to the lower weights (i. e. completely)."

This is why the preposition $r$ can never mark the spatial functions of course. For the same reason, this preposition is, on the contrary, bound to mark the adessive of inanimate entities. This function is quite clear in passages speaking about burials $\left(\mathrm{sm}_{3} \mathrm{H}^{-} \mathrm{t}^{3}\right)$ in relation to a town, which is usually introduced by the preposition $r .{ }^{34}$

\section{Ex. 30 (CT V 17 c)}

$$
\begin{array}{lcc}
s m 3-t 3 & r & \text { iwnw } \\
\text { join-earth } & \text { to } & \text { Heliopolis } \\
\text { "To be buried at Heliopolis." }
\end{array}
$$

The notion of limit is also what explains why the preposition $r$ must be selected to mark the future III tense $(r+$ infinitive), relation, opposition, finality, promotion, destiny, model and compari-

32 see VERNUS (1987) 173.

33 In this passage, a previous series of negative jussives (subjunctive $s \underline{d} m . f+$ negative particle $w$ ) is legitimised by the officiant in order to avoid the fishermen capturing the deceased.

34 see also CT V $64 \mathrm{~d}$, V $65 \mathrm{~d}, \mathrm{~V} 166 \mathrm{j}$. With the preposition $m$ in CT V 14 c, V $14 \mathrm{j}$ : In these cases it is perhaps the ensemble of town and necropolis that should be understood. 
son standard. Semantic extensions such as these have been dealt with elsewhere. ${ }^{35}$

Nevertheless, the notion of limit is not a feature exclusive to the preposition $r$ : It is also pertinent for the prepositionconjunction $\underline{d} r$, which introduces clauses of anterior, posterior but not concomitant time. Be that as it may, what is more important here is the fact that some entities possessing interior space also have the "limit" feature, although it is only "activated" in a critical case: With verbs whose meaning is strongly linked to the limits of entities, especially if those verbs are achievements, i. e. punctual and telic actions that happen precisely at a limit. This is, first of all, the case of the verb ' $q$ "enter": An achievement whose meaning implies the access to an entity possessing interior space. This is quite clear in comparing

\section{Ex. 31 (CT III 238 a-239 b)}

$$
\begin{array}{lccc}
h m s .(w) . k & r . k \quad \underline{h r} \quad s m 3 . w \\
\text { sit.FUT.2SGM IMPL under } & \text { branch.PLM }
\end{array}
$$

nh.wt 'ntyw m-s3h.t hw.t-hr

trees.PLF myrrh in-touching.SGF Hathor $^{36}$

"You $(=\mathrm{N})$ shall sit down under the branches of the myrrh-trees, touching Hathor."

with

\section{Ex. 32 (CT III 237 b-239 b)}

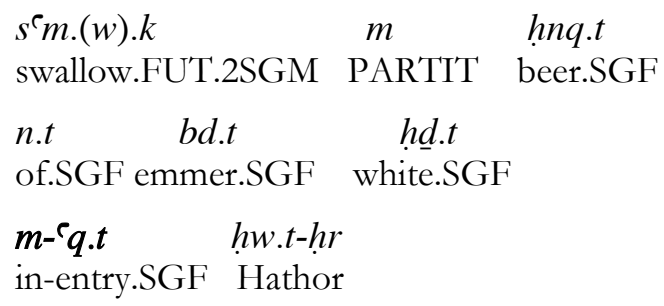

35 GRACIA (2008) § 7.

36 A goddess' proper name. 
"You shall swallow beer of white emmer at the entry of Hathor."

The same is true in

\section{Ex. 33 (CT IV $329 \mathrm{~m}$ )}

\section{n m3.n.sn 'q r-hn.w.s \\ NEG see.PFV.3PL go-in to-inside.3SGF}

"One can not see the entry into (lit. to the inside) it (= a porch)."

In the Coffin Texts, the verb $q$ is never accompanied by a SA of provenance nor allatives of entities possessing interior space, but only by two allatives of entities lacking interior space ${ }^{37}$, which clearly shows this very particular meaning. Precisely because of this particularity, the prepositions marking the illative with this verb undergo changes.

At first sight, one might think that such changes are a specific characteristic of the SA expressing a limit and through which the action of "entering" is performed, i. e. doors. But, after an exhaustive examination of all the SAs with the verb ' $q$, there is no doubt that this kind of entity behaves like the rest of SAs possessing interior space ${ }^{38}$.

In consequence, the explanation of this alteration for the illative must be found elsewhere. As a matter of fact, there is a difference between the entities of illative SAs with the verb ${ }^{c} q$ that are marked by $m$ (the general mark for the illative) and those marked, surprisingly, by $r$ (the usual mark for allative inanimates). G. Lakoff and M. Johnson again contribute a theoretical reflection that perfectly explains this phenomenon in Egyptian. These authors consider containers (i. e. entities with boundaries) to be divided into substances (e. g. water) and objects (e. g. tub). ${ }^{39}$ These two kinds of entities exactly map the data from the Coffin Texts concerning

37 CT IV 290 c-291 c (B9Ca), CT VI 388 m.

38 At least for the coursive and endo-coursive, which are the only spatial functions attested with doors as SAs of the verb ' $q$.

39 LAKOFF - JOHNSON (1980) 30. 
illatives with the verb ' $q$, respectively marked by $m$ or $r$. Entities possessing interior space must then be further distinguished: Those without limits (Lakoff's and Johnson's substances) have the illative with the verb ' $q$ marked by $m$; but those with limits (Lakoff's and Johnson's objects) have the illative marked by $r$. Those marked by $m$ are masses, for instance, fire, liquids, earth, air; it should be noted that the same preposition is also used to mark the partitive, which is only possible with masses. ${ }^{40}$ Whereas those marked by $r$ are entities with limits, like body parts, buildings and building parts, towns and geographical places. Here are two examples, respectively:

\section{Ex. 34 (CT VII 30 a)}

$\begin{array}{llclc}r & n & { }^{c} q & m & t 3 \\ \text { spell } & \text { of } & \text { go-in } & \text { in } & \text { earth }\end{array}$

"Spell of going into the earth."

\section{Ex. 35 (CT II 290 b-291 b)}

$\begin{array}{lllrr}{ }^{e} q & r \quad p r & w s i r & n & \underline{d} d w \\ \text { go-in } & \text { to house } & \text { Osiris } & \text { of } & \text { Busiris }\end{array}$

"To go into the temple of Osiris of Busiris."

Still, this is not a phenomenon exclusive to the verb ${ }^{\mathrm{C}} q$ : There is a full series of verbs, with different degrees of transitivity, that also imply the notion of limit, which is why their SAs or circumstantial adjuncts are predominantly marked by the preposition $r$. These are verbs that express:

- an action affecting the exterior part of an entity, that part being a surface or a point, a part that is a target ${ }^{41}$ (e. g. w3h "place down", $s \underline{t} i$ "cast, throw", $d m i$ " touch") or

40 LAZARD (1994) 191-204.

41 For this kind of verb, see GARDINER (1957) \& 163.1. The related expression $d m \underline{d} r$ "total" (lit. "put together to"), which strongly implies the notion of limit, is commented by JAMES (1962) 39. 
- a negative or dangerous reference point ${ }^{42}$ (e. g. imn "hide", w3i "be far" $43,23 w$ "keep out").

For example, respectively:

\section{Ex. 36 (CT VI 295 i)}

$$
\begin{array}{lclc}
s t(i) . f & p 3 z . k & r & t 3 \\
\text { throw.3SGM } & \text { bowl.2SGM } & \text { to } & \text { earth }
\end{array}
$$

"May he $(=\mathrm{N})$ cast your ${ }^{44}$ bowl to the ground!"

\section{Ex. 37 (CT VII $41 \mathrm{~g}$ )}

$$
\begin{array}{lcccc}
z 3 & \stackrel{t w}{w} & \boldsymbol{r} & \breve{s} & w r \\
\text { keep-out } & 2 \mathrm{~S} G \mathrm{M} & \text { from } & \text { lake } & \text { great }
\end{array}
$$

Further study must be done on these verbs in order to properly understand their "Aktionsart" and valential structure. 45

\section{THE SPATIAL ADJUNCT}

Destination is the most frequently expressed spatial function: This is not surprising ${ }^{46}$, since destination is the psycholinguistically predominant spatial function. ${ }^{47}$ The second spatial function in frequency is course, and then provenance. In other words: There is a scale of space (provenance being the least frequent, and destination the most) that parallels a scale of information: Provenance, where the first participant is prototypically placed, is the least informative element; destination, where the second participant is prototypically

\footnotetext{
42 For this kind of verbs, see GARDINER (1957) \ 163.8.

43 For this verb, see FRANKE (1998).

44 gbg3-bird's.

45 see WINAND (2006) 125, n. 113.

46 see mainly BOONS (1988) 35, table S; LAMIROY (1988) 50_

47 Clark - GARnikA (1974) 559. 568. 570. 571; Clark (1978) 112, n. 5. 116; VANDELOISE (1988) 109 and n. 13; RICHARD - VERSTIGGEL (1990) 119.
} 51. 
placed, is the most informative. ${ }^{48}$ This fact seems to confirm S. Delancey's hypothesis that there is a flow of attention from the source to the goal (both terms in the broad sense). ${ }^{49}$ These two scales parallel a scale of transitivity ${ }^{50}$, but only partially: Among all the SAs without a preposition $(\varnothing), 68.9 \%$ are courses, $27.3 \%$ destinations (of which $77.7 \%$ are illative), and $3.8 \%$ are provenances. In fact, course is mainly marked by $\varnothing$, then by $h r$, less frequently by $m$ and never by $r$. The favoured marking of this spatial function by $\varnothing$ proves the semantic proximity between the SA and the direct object: Both belong to the objectal zone. ${ }^{51}$

On the other hand, among the 26 cases of alternation preposition / Ø attested in the Coffin Texts, the preposition $m$ occurs 14 times ( 6 endo-coursive, 5 illative and 3 elative), the preposition $r 7$ times (6 allative and 1 adessive) and the preposition $h r 5$ times (2 coursive, 2 conclusive and 1 essive). In other words, the preposition $h r$, which does not have the "interior space" feature, rarely tends to alternate with $\varnothing$, whilst the prepositions $m$ and $r$, which have that feature, easily alternate with $\varnothing$, especially $m$. The "interior space" feature of these two prepositions brings them near to the mark of the direct object $(\varnothing)$, because the action of motion "affects" the SA more completely if it happens inside of it (in which case $m$ is used) or at least at its limit (in which case $r$ is used). In short: The "interior space" feature is close to the "transformation" feature which is characteristic of the typical direct object: The patient. This explains why the most frequent alternation preposition / $\varnothing$ is $m / \varnothing$. Nor is it a coincidence that animates, typically subjects and indirect objects, have no interior space. It will be recalled here that D. R. Dowty considers the "movement" feature to be a characteristic of the agent (as opposed to the patient). ${ }^{52}$ The alternation $m / \varnothing$ and the preferential marking of $\varnothing$ for the spatial function of course prove the existing continuum in the objectal zone between

48 see VANDELOISE (1988) 77; CIFUENTES (1999) 110.

49 DelanCEY (1981); LAZARD (1994) 226.

50 see HOPPER - THOMPSON (1980) 266 (mainly); WINAND (2006) 90. 122.

51 LAZARD (1994) 95-96. 98. 123. 138.

52 DOWTY (1991) 572. 
the direct object ${ }^{53}$ and the SA: The spatial function of course (especially, the endo-coursive) and the illative are semantically very close to the patient. ${ }^{54}$ As we saw in 4 , we should add to this interpretation that the indirect object (typically, the beneficiary) is semantically close to the allative (animate). In conclusion, there seems to be a correspondence among the three linguistic viewpoints (semantic, pragmatic and syntactic), with three corresponding scales: of space, information and transitivity.

To sum up the semantic description of the SAs proposed in this paper, I shall show the prepositions that mark spatial functions as they occur in the Coffin Texts in twelve tables, ordered by spatial function: locative (essive, inessive, adessive), course (coursive, endo-coursive, exo-coursive), destination (conclusive, illative, allative), and provenance (originating, elative, ablative). The most frequent prepositions are written in bold letters. The absence of preposition is indicated by $\varnothing$. The prepositions under study are: $h r-$ $3 w$ "along", (m)-hr-ib "in the middle", imytw "between", hr-`.wy / (n)-tp-`.wy "in front of", $m-{ }^{-} q . t$ "at the entry of", $m-b 3 h$ "in the presence of", $m$ "in", $m m$ "among", $n$ "to", $r$ "to, out of", $r$ rmn.wy "beside", $h 3$ "around, behind", $r-h 3$ "to the neighbourhood, to the behind", $m-h$ 3.t "in front of", $h r$ "on, at", $n-h r$ "in front of", hft (-hr) "opposite", (m)-hnt "in front of, ahead", hr-hht "at / by the front of", $r$-hnt "to the front of", hr "by, to", $m$ - hsf.w "opposite", ht "all along", $m$ / hr-ht "behind", (m)-hhtht.(w) "along", $m-\underline{h} n . w$ "inside", $r-\underline{h n} . w$ "into", $h r$ "under", $m / r-s$ 3 "behind", m-s3h.t "touching, close to", $r$-gs "beside", tp "over, towards", $m$-tp "over", $r$-tp "to the front of", $h r-t p$ "on top of" and tp-m "towards".

53 The opposition $m / \varnothing$ in marking the direct object is a perennial subject of discussion in Egyptological literature that will not be commented on here. see JAMES (1962) 104; SILVERMAN (1980); MALAisE - WinAND (1999) \431; WinAND (2006) 89. 137-149; PEUST (2008).

54 I leave this matter, concerning the "Aktionsart" of the verbs implied, for later publication. see LEVIN - RAPPAPORT (1992) 261; CIFUENTES (1999) 106. 109. 131-133; WINAND (2006) 130. 139; see also DowTY (1991) 569 (for the related subject of the incremental theme). 


\subsection{LOCATIVE}

\begin{tabular}{|c|c|c|c|}
\hline ESSIVE & $\begin{array}{l}\text { Inanimate } \\
\text { (divine \& not) }\end{array}$ & Animate & Animate $\&$ divine \\
\hline $\begin{array}{l}\text { With } \\
\text { interior space }\end{array}$ & $h r, h t, t p$ & - & $h r, t p-\ulcorner. w y, m-h s f . w$ \\
\hline $\begin{array}{l}\text { Without } \\
\text { interior space }\end{array}$ & $h r, \varnothing, m^{55}$ & $h r, t p, m-h s f . w$ & - \\
\hline
\end{tabular}

Table 2

\begin{tabular}{|c|c|c|c|}
\hline INESSIVE & $\begin{array}{l}\text { Inanimate } \\
\text { (divine \& not) }\end{array}$ & Animate ${ }^{56}$ & Animate $\&$ divine \\
\hline $\begin{array}{l}\text { With } \\
\text { interior space }\end{array}$ & $\begin{array}{l}m, \varnothing,(m)-\underline{h r} r i b \\
i m y t w, m-\underline{h} n . w\end{array}$ & $m, m m$ & $\begin{array}{l}m, m-h r-i b, i m y t w, \\
m m\end{array}$ \\
\hline $\begin{array}{l}\text { Without } \\
\text { interior space }\end{array}$ & - & - & - \\
\hline
\end{tabular}

Table 3

\begin{tabular}{|c|c|c|c|}
\hline ADESSIVE & $\begin{array}{l}\text { Inanimate } \\
\text { (divine \& not) }\end{array}$ & Animate & Animate $\&$ divine \\
\hline $\begin{array}{l}\text { With } \\
\text { interior space }\end{array}$ & $\begin{array}{l}r, \varnothing, h 3, h n t, m- \\
h n t, m-s 3, m-t p, \\
h r-t p\end{array}$ & - & $\begin{array}{l}m-h n t, m-b 3 h, r^{57}, r- \\
r m n . w y, h 3, m-h 3 . t, \\
h f t, h n t, h r, m-s 3 h . t, \\
m-{ }^{-} q . t, r-g s, m-t p, \\
h r-t p, \varnothing\end{array}$ \\
\hline $\begin{array}{l}\text { Without } \\
\text { interior space }\end{array}$ & $r, h 3, \underline{h r}$ & 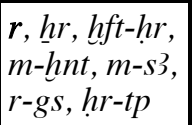 & - \\
\hline
\end{tabular}

Table 4

55 An exception to my description: CT III $114 \mathrm{~d}$ (with w3.t "way").

56 Only collectives.

57 With verbs implying the notion of limit (see paragraph 5). 
6.2. Course

\begin{tabular}{|c|c|c|c|}
\hline COURSIVE & $\begin{array}{l}\text { Inanimate } \\
\text { (divine \& not) }\end{array}$ & Animate & Animate \& divine \\
\hline $\begin{array}{l}\text { With } \\
\text { interior space }\end{array}$ & $\varnothing, h r, h t, t p$ & - & $\boldsymbol{\varnothing}, h \mathrm{~h} r, h r-3 w$ \\
\hline $\begin{array}{l}\text { Without } \\
\text { interior space }\end{array}$ & $\begin{array}{l}\text { Ø, har, ht, htht, } \\
t p\end{array}$ & $\varnothing, h r$ & - \\
\hline
\end{tabular}

Table 5

\begin{tabular}{|c|c|c|c|}
\hline $\begin{array}{l}\text { ENDO- } \\
\text { COURSIVE }\end{array}$ & $\begin{array}{l}\text { Inanimate } \\
\text { (divine \& not) }\end{array}$ & Animate ${ }^{58}$ & Animate $\&$ divine \\
\hline $\begin{array}{l}\text { With } \\
\text { interior space }\end{array}$ & $\begin{array}{l}\boldsymbol{\emptyset}, m, h r-i b, m- \\
\underline{h n} . w, i m y t w\end{array}$ & $m m, m$ & $\begin{array}{l}\boldsymbol{\varnothing}, \text { imytw, } m, m m, \\
m \text {-htht.w }\end{array}$ \\
\hline $\begin{array}{l}\text { Without } \\
\text { interior space }\end{array}$ & - & - & - \\
\hline
\end{tabular}

Table 6

\begin{tabular}{|c|c|c|c|}
\hline $\begin{array}{l}\text { EXO- } \\
\text { COURSIVE }\end{array}$ & $\begin{array}{l}\text { Inanimate } \\
\text { (divine \& not) }\end{array}$ & Animate & Animate $\&$ divine \\
\hline $\begin{array}{l}\text { With } \\
\text { interior space }\end{array}$ & $\begin{array}{l}\boldsymbol{\varnothing}, h 3, \underline{h r}-h n t \\
h r, h r-t p\end{array}$ & $\underline{h} r^{59}$ & $\boldsymbol{\varnothing}, m-b 3 \underline{h}, \underline{h} 3, \underline{h} r$ \\
\hline $\begin{array}{l}\text { Without } \\
\text { interior space }\end{array}$ & $h r-t p$ & $\begin{array}{l}\boldsymbol{\varnothing}, h 3, h f t, \\
h f t-h r\end{array}$ & - \\
\hline
\end{tabular}

Table 7

58 Only collectives.

59 Collective. 


\subsection{Destination}

\begin{tabular}{|c|c|c|c|}
\hline CONCLUSIVE & $\begin{array}{l}\text { Inanimate } \\
\text { (divine \& not) }\end{array}$ & Animate & Animate \& divine \\
\hline $\begin{array}{l}\text { With } \\
\text { interior space }\end{array}$ & $\begin{array}{l}h r, h r-h c t, t p, \\
t p-m, \varnothing\end{array}$ & - & $\begin{array}{l}n-t p-\ulcorner. w y, h r, m- \\
h s f . w, m-h t, t p-m\end{array}$ \\
\hline $\begin{array}{l}\text { Without } \\
\text { interior space }\end{array}$ & $h r, m^{60}$ & $\begin{array}{l}h r-r . w y, t p- \\
\ulcorner. w y, h r, m- \\
h s f . w, m-h t\end{array}$ & - \\
\hline
\end{tabular}

Table 8

\begin{tabular}{|c|c|c|c|}
\hline ILLATIVE & $\begin{array}{l}\text { Inanimate } \\
\text { (divine \& not) }\end{array}$ & Animate & Animate $\&$ divine \\
\hline $\begin{array}{l}\text { With } \\
\text { interior space }\end{array}$ & $\begin{array}{l}m, h r-i b, \\
i m y t w, r^{61}, m- \\
\underline{h} n . w, r-\underline{h} n . w, \\
\varnothing\end{array}$ & $\begin{array}{l}m m, m \\
\text { imytw }^{62}\end{array}$ & $m$, imytw, $m m, r^{63}, \varnothing$ \\
\hline $\begin{array}{l}\text { Without interior } \\
\text { space }\end{array}$ & - & $m^{64}$ & - \\
\hline
\end{tabular}

Table 9

${ }^{60}$ Plurals.

61 With the verb ' $q$ and similar (see paragraph 5) and the expression $h 3 i+r+$ bark "to embark".

62 These three prepositions, only with collectives.

${ }^{63}$ With the verb ${ }^{\circ} q$.

64 The deceased in the sense of "body" (see paragraph 3). 


\begin{tabular}{|c|c|c|c|}
\hline ALLATIVE & $\begin{array}{l}\text { Inanimate } \\
\text { (divine \& not) }\end{array}$ & Animate & Animate \& divine \\
\hline $\begin{array}{l}\text { With } \\
\text { interior space }\end{array}$ & $\begin{array}{l}r, m-b 3 h, r-h 3, \\
m-h n t, r-h n t, \\
h r, m-s 3, r-t p, \\
\varnothing\end{array}$ & - & $\begin{array}{l}h r, m-b 3 h, r^{65}, h 3, m- \\
h 3 . t, h f t, h n t, h r, m- \\
s^{3}, r-g s, r-t p, \varnothing\end{array}$ \\
\hline $\begin{array}{l}\text { Without } \\
\text { interior space }\end{array}$ & $r, r-h n t, \underline{h} r, \varnothing$ & $\begin{array}{l}n, r^{66}, h 3, \\
\underline{h} r, m-s 3\end{array}$ & - \\
\hline
\end{tabular}

Table 10

\subsection{Provenance}

\begin{tabular}{|l|l|l|l|}
\hline ORIGINATING & $\begin{array}{l}\text { Inanimate } \\
\text { (divine \& not) }\end{array}$ & Animate & Animate \& divine \\
\hline $\begin{array}{l}\text { With } \\
\text { interior space }\end{array}$ & $h r, m-h t, t p$ & - & - \\
\hline $\begin{array}{l}\text { Without } \\
\text { interior space }\end{array}$ & $h r$ & - & - \\
\hline
\end{tabular}

Table 11

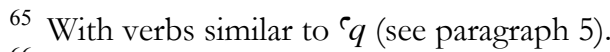

${ }^{66}$ With verbs similar to $q$ (see paragraph 5). 
The SPATIAL AdJUNCT| 249

\begin{tabular}{|l|l|l|l|}
\hline ELATIVE & $\begin{array}{l}\text { Inanimate } \\
\text { (divine \& not) }\end{array}$ & Animate & Animate \& divine \\
\hline $\begin{array}{l}\text { With } \\
\text { interior space }\end{array}$ & $\begin{array}{l}m, r^{67}, \\
m-\underline{h} n \cdot w, \\
r-\underline{h} n \cdot w^{68}, \varnothing\end{array}$ & $m^{69}, \mathrm{~mm}^{70}$ & $m, m m, \varnothing$ \\
\hline $\begin{array}{l}\text { Without } \\
\text { interior space }\end{array}$ & $m^{71}$ & - & - \\
\hline
\end{tabular}

Table 12

\begin{tabular}{|l|l|l|l|}
\hline ABLATIVE & $\begin{array}{l}\text { Inanimate } \\
\text { (divine \& not) }\end{array}$ & Animate & Animate \& divine \\
\hline $\begin{array}{l}\text { With } \\
\text { interior space }\end{array}$ & $r, \underline{h} r, r-s\}$ & - & $m-h n t, r-g s, r^{72}$ \\
\hline $\begin{array}{l}\text { Without } \\
\text { interior space }\end{array}$ & $\underline{h} r$ & $\underline{h} r$ & - \\
\hline
\end{tabular}

Table 13

Dr. CARLOS Gracia Zamacona

C/ Santa Hortensia, 43-11 H.

28002 - Madrid (Spain).

e-mail: cruciral@yahoo.es

${ }^{67}$ Due to the influence of the verb ' $q$ (factorized pri and ${ }^{\circ} q$ "go out and in"; alternation $\check{s} m$ / 'q"go / enter").

${ }^{68}$ Due to the influence of the verb ' $q$ (factorized pri and ' $q$ "go out and in").

${ }^{69}$ Collectives or resumptives. CT VII $486 \mathrm{~g}(m+n r w . t$ "out of the vulture") is an exception to this description.

${ }^{70}$ Collective.

71 Two cases: One is a dual (CT III 33 a: sp.ty "lips") and the other seems to be a mistake (CT III 257 c (B1L)).

${ }^{72}$ With verbs implying the notion of limit (see 5). 


\section{BIBLIOGRAPHY}

ALLEN (2000)

J. P. Allen, Middle Egyptian. An Introduction to the Language and Culture of Hieroglyphs (Cambridge 2000).

ANDERSON (1971)

J. M. Anderson, The Grammar of Case. Towards a Localistic Theory (Cambridge 1971).

ANTHES (1954)

R. Anthes, The Original Meaning of $m 3^{\top}$ hrw, Journal of Near Eastern Studies 13, 1954, 21-51.

ANTHES (1969)

R. Anthes, Zur Übersetzung der Präpositionen und Konjunktionen $m$ und $\underline{d} r$, in: E. B. Hauser (ed.), Studies in Honor of John A. Wilson, Studies in Ancient Oriental Civilization 35 (Chicago 1969) 1-13.

ASSMANN (2001)

J. Assmann, Tod und Jenseits im Alten Ägypten (München 2001).

BENNETT (1972)

D. C. Bennett, Some Observations Concerning the Locativedirectional Distinction, Semiotica 5, 1972, 58-88.

BERTHONNEAU - CADIOT (1993)

A. M. Berthonneau - P. Cadiot (eds.), Les prépositions: méthodes d'analyse, Lexique 11 (Lille 1993).

BOONS (1988)

J. P. Boons, La notion sémantique de déplacement dans une classification syntaxique des verbes locatifs, in: C. Vandeloise (ed.), L'expression du mouvement, Langue Française 76 (Paris 1988) 5-40. 
BRøNDAL (1950)

V. Brøndal, Théorie des prépositions. Introduction à une sémantique rationnelle (Copenhague 1950).

BRUNNER-TRAUT (2002)

E. Brunner-Traut, Aspective, in: H. Schäfer (ed.), Principles of Egyptian Art (Oxford 2002) 421-448.

Cifuentes (1999)

J. L. Cifuentes, Sintaxis y semántica del movimiento. Aspectos de gramática cognitiva (Elche 1999).

CLARK (1978)

E. V. Clark, From Gesture to Word: On the Natural History of Deixis, in: J. S. Bruner - A. Garton (eds.), Human Growth and Development (Oxford 1978) 85-120.

CLARK - GARNIKA (1974)

E. V. Clark - O. K. Garnika, Is He Coming or Going? On the Acquisition of Deictic Verbs, Journal of Verbal Learning and Verbal Behavior 13, 1974, 559-572.

CLERE (1941-1947)

J. J. Clère, Sur un emploi parallèle des prépositions arabe littéral $b i$ - et ancien égyptien $m$, Comptes rendus du Groupe Linguistique d'Etudes Chamito-Sémitiques 4, 1941-1947, 24-25.

CT

A. De Buck, The Egyptian Coffin Texts I-VII, Oriental Institute Publications 24, 49, 64, 67, 73, 81, 87 (Chicago 19351961).

COMrIE - SMITH (1977)

B. Comrie - N. Smith, Lingua Descriptive Studies: Questionnaire, Lingua 42.1, 1977, 3-71. 
DANEŠ (1964)

F. Daneš, A Three-Level Approach to Syntax, in: J. Vachek (ed.), Travaux Linguistiques de Prague I (Prague 1964) 225240.

DEINES - WESTENDORF (1957)

H. von Deines - W. Westendorf, Zur ägyptischen Wortforschung V. Proben aus den Worterbüchern zu den medizinischen Texten, Abhandlungen der deutschen Akademie der Wissenschaften zu Berlin, Klasse für Sprachen, Literatur und Kunst 1956, 6 (Berlin 1957).

DELANCEY (1981)

S. Delancey, Aspect, Transitivity and Viewpoint, in: P. J. Hopper (ed.), Tense-Aspect: Between Semantics and Pragmatics. Containing the Contributions to a Symposium on Tense and Aspect, held at UCLA, May 1979, Typological Studies in Language 1 (Amsterdam 1981) 167-183.

DEPUYDT (1985a)

L. Depuydt, A propos de la notion de mouvement en copte et en égyptien, Chronique d'Egypte 60, 1985, 85-95.

DEPUYDT (1985b)

L. Depuydt, On the Notion of Movement in Egypto-Coptic and Hebrew, in: S. Israelit-Groll (ed.), Pharaonic Egypt. The Bible and Christianity (Jerusalem 1985) 30-37.

DERVILLEZ-BASTUJI (1982)

J. Dervillez-Bastuji, Structure des relations spatiales dans quelques langues naturelles: introduction à une théorie sémantique (Genève 1982).

DIEHL (1975)

L. Diehl, Space Case: Some Principles and their Implications Concerning Linear Order in Natural Languages, Working Papers of the Summer Institute of Linguistics, University of North Dakota 19, 1975, 93-150. 
DOWTY (1991)

D. R. Dowty, Thematic Proto-Roles and Argument Selection, Language 67.3, 1991, 547-620.

EDEL (1955-1964)

E. Edel, Altägyptische Grammatik I-II, Analecta Orientalia 34-39 (Roma 1955-1964).

ENGLUND (1999)

G. Englund, The Border and the Yonder Side, in: E. Teeter J. A. Larson, Gold of praise, Studies on Ancient Egypt in Honor of Edward F. Wente, Studies in Ancient Oriental Civilization 58 (Chicago 1999) 101-109.

ERMAN (1928)

A. Erman, Ägyptische Grammatik, Porta Linguarum Orientalium $15^{4}$ (Berlin 1928).

FILLMORE (1966)

Ch. J. Fillmore, Deictic Categories in the Semantics of

"Come", Foundations of Language 2, 1966, 219-227.

FILLMORE (1968)

Ch. J. Fillmore, The Case for Case, in: E. Bach - R. T. Harms (eds.), Universals in Linguistic Theory (New York 1968) 1-88.

FILLMORE (1983)

Ch. J. Fillmore, How to Know Whether You Are Coming or Going, in: G. Rauh (ed.), Essays on Deixis (Tübingen 1983) 219-229.

FRANKE (1998)

D. Franke, Das Entfernen eines Sprachtabus. Nochmals zur Konstruktion w3j r, Göttinger Miszellen 165, 1998, 51-56.

GARDINER (1957)

A. H. Gardiner, Egyptian Grammar. Being an Introduction to the Study of Hieroglyphs (Oxford 1957). 
GOEDICKE (1955)

H. Goedicke, The Egyptian Idea of Passing from Life to Death (an Interpretation), Orientalia 24, 1955, 225-239.

GRACIA (2008)

C. Gracia, Les verbes de mouvement dans les Textes des Sarcophages, Étude sémantique (PhD thesis Ecole Pratique des Hautes Etudes Paris 2008).

GuILLEMIN (1920)

A. Guillemin, La préposition de dans la littérature latine (Paris 1920).

HAGEGE (1996)

C. Hagège, L'homme de paroles (Paris 1996).

HANNIG et al. (1986)

R. H. G. Hannig - R. F. Huang - R. M. Ling Hu, A Note on the Use of Egyptian Prepositions, Journal of Ancient Civilizations 1, 1986, 145-147.

HJELMSLEV (1935)

L. Hjelmslev, La catégorie des cas. Étude de grammaire générale, Acta Jutlandica 7 (Aarhus 1935).

HOPPER - THOMPSON (1980)

P. J. Hopper - S. A. Thompson, Transitivity in Grammar and Discourse, Language 56, 1980, 251-299.

HORNUNG (1996)

E. Hornung, L'esprit du temps des pharaons (Paris 1996).

JAMES (1962)

T. G. H. James, The Hekanakhte Papers and Other Early Middle Kingdom Documents (Oxford 1962).

JESPERSEN (1924)

O. Jespersen, The Philosophy of Grammar (London 1924). 
JUNGE (1973)

F. Junge, Satz und Feld. Versuch zur deskriptiven Semantik toter Sprachen am Beispiel mittelägyptischer Präpositionen, Göttinger Miszellen 6, 1973, 61-90.

KURILOWICZ (1949)

J. Kuriłowicz, Le problème du classement des cas, in: Esquisses Linguistiques 1, Wrocław 1969, 131-150.

LAFFORD (1986)

B. Lafford, Ser y estar. Una nueva dimensión, in: Actas del $2^{\circ}$ Congreso Internacional del Español de América (México 1986) 553-564.

LAKOFF - JOHNSON (1980)

G. Lakoff - M. Johnson, Metaphors We Live by (Chicago 1980).

LAMIROY (1988)

B. Lamiroy, Les verbes de mouvement, emplois figurés et extensions métaphoriques, in: C. Vandeloise (ed.), L'expression du mouvement, Langue Française 76 (Paris 1988) 41-58.

LANGACKER (1987)

R. W. Langacker, Foundations of Cognitive Grammar I (Stanford 1987).

LAZARD (1994)

G. Lazard, L'actance (Paris 1994).

Le Page RenOuf (1873)

P. Le Page Renouf, Note on Egyptian prepositions, Transactions of the Society of Biblical Archaeology 2, 1873, 301-320.

LEMARECHAL (1989)

A. Lemaréchal, Les parties du discours. Sémantique et syntaxe (Paris 1989). 
LETOUBLON (1985)

F. Létoublon, Il allait, pareil à la nuit. Les verbes de mouvement en grec: supplétisme et aspect verbal (Paris 1985).

LEVIN - RAPPAPORT (1992)

B. Levin - H. M. Rappaport, The Lexical Semantics of Verbs of Motion: The Perspective from Unaccusativity, in: I. M. Roca (ed.), Thematic Structure: Its Role in Grammar (Berlin 1992) 247-269.

LOPEZ (1970)

M. L. López, Problemas y métodos en el análisis de preposiciones (Madrid 1970).

LOPRIENO (1995)

A. Loprieno, Ancient Egyptian. A Linguistic Introduction (Cambridge 1995).

LYONS (1971)

J. Lyons, Introduction to Theoretical Linguistics (Cambridge 1971).

LYONS (1994)

J. Lyons, Semantics (Cambridge 1994).

MALAISE - WINAND (1999)

M. Malaise - J. Winand, Grammaire raisonnée de l'égyptien classique, Aegyptiaca Leodinensia 6 (Liège 1999).

PALMER (1994)

F. R. Palmer, Grammatical Roles and Relations (Cambridge 1994).

PAPAHAGI (2005)

Ch. Papahagi, Les prépositions de trajectoire en français et en roumain. Etude synchronique et diachronique (PhD thesis Université Sorbonne Nouvelle Paris 3 2005). 
PEUST (2008)

C. Peust, Wie fokussiert man im Ägyptischen ein direktes Objekt?, Zeitschrift für Ägyptische Sprache und Altertumskunde 135, 2008, 78-87.

POLOTSKY (1965)

H. J. Polotsky, Egyptian Tenses, in: Israel Academy of Sciences and Humanities Proceedings 2.5, 1965, 1-25.

POTTIER (1962)

B. Pottier, Systématique des éléments de relation. Etude de syntaxe structurelle romane (Paris 1962).

PT

K. Sethe, Die altägyptischen Pyramidentexte I-IV (Leipzig 1908-1922).

RICHARDS - VERSTIGGEL (1990)

J. F. Richard - J. C. Verstiggel, La représentation de l'action dans les processus de compréhension, in: J. François - G. Denhière (eds.), Cognition et langage. Les types de prédications en sémantique linguistique et psychologique, Langages 100 (Paris 1990) 115-126.

ROCCATI (1975)

A. Roccati, Scambio delle preposizioni $n / r$ in egiziano, Annali del Istituto Orientale di Napoli 35, 1975, 245-247.

SAINT-DIZIER (2005)

P. Saint-Dizier, Introduction to the Syntax and Semantics of Prepositions, in: P. Saint-Dizier (ed.), Text, Speech and Language Technology 29 (Berlin 2005) 1-24.

SANDER-HANSEN (1956)

C. E. Sander-Hansen, Studien zur Grammatik der Pyramidentexte, Analecta Aegyptiaca 4 (Copenhague 1956). 
SILVERMAN (1980)

D. P. Silverman, An Emphasized Direct Object of a Nominal Verb in Middle Egyptian, Orientalia 49, 1980, 199-203.

SMITHER (1939)

P. C. Smither, A New Use of the Preposition $m$, Journal of Egyptian Archaeology 25, 1939, 166-169.

SVOROU (1994)

S. Svorou, The Grammar of Space, Typological Studies in Language 25 (Amsterdam 1994).

VANDELOISE (1988)

C. Vandeloise, La préposition à et le principe d'anticipation, in: C. Vandeloise (ed.), L'expression du mouvement, Langue Française 76 (Paris 1988) 77-111.

VERNUS (1987)

P. Vernus, Etudes de philologie et de linguistique VI, Revue d'Egyptologie 38, 1987, 163-181.

WAUGH (1976)

L. Waugh, Lexical Meaning: The Prepositions en and dans in French, Lingua 39, 1976, 69-118.

WINAND (2006)

J. Winand, Temps et aspect en égyptien. Une approche sémantique, Probleme der Ägyptologie 25 (Leiden 2006). 